Historia Slavorum Occidentis

2020, $\mathrm{nr} 1$ (24)

ISSN 2084-1213

DOI: $10.15804 /$ hso200106

Michą Zwierzykowski (PoznaŃ)

ORCID 0000-0002-6419-3222

\title{
Wpływ unii personalnej z Saksonią na funkcjonowanie systemu parlamentarnego Rzeczypospolitej Obojga Narodów
}

Słowa kluczowe: Polska, Saksonia, historia, ustrój, parlamentaryzm, unie

Keywords: Poland, Saxony, history, state organization, parliamentary systems, commonwealth

\begin{abstract}
This article attempts to provide answers to several research questions related to the consequences of representatives of the House of Wettin ruling the Polish-Lithuanian Commonwealth to the country's state organisation, with special emphasis placed on its parliamentary system.
\end{abstract}

W 1996 r. Mariusz Markiewicz, krakowski historyk, znawca problematyki związanej z funkcjonowaniem ustroju Rzeczypospolitej w epoce unii z Saksonią, opublikował tekst zawierający prowokującą do przemyśleń i dyskusji tezę, która ogniskowała się wokół stwierdzenia, że państwo szlacheckie mogło doskonale obejść się bez sejmu (jeśli tylko nie prowadziło wojen i nie chciało się reformować), a wiele funkcji sejmowych przejąć miały w tym czasie inne instytucje, jak sejmiki, trybunały, czy wreszcie, wydawałoby się, najwłaściwsze po temu, rady senatu ${ }^{1}$. Teza ta pozostawała w pewnej sprzeczności z wcześniejszymi ustaleniami tego historyka, zapisanymi

1 M. Markiewicz, Rzeczpospolita bez sejmu. Funkcjonowanie państwa, [w:] Między barokiem a oświeceniem. Nowe spojrzenie na czasy saskie, red. K. Stasiewicz, S. Achremczyk, Olsztyn 1996, s. $175-179$. 
między innymi w jego rozprawie poświęconej radom senatu za panowania Augusta II, w której napisał między innymi, że rady „nie mogły w sposób należyty spełniać roli najwyższej władzy wykonawczej, ponieważ zakres ich władzy był niewielki. [...] nie starały się zastępować sejmu i jeżeli niekiedy można zaobserwować takie tendencje ze strony królewskiej, to legalizm senatorów uniemożliwiał to przedsięwzięcie”2. W innym ze swoich artykułów, dotyczącym roli senatu jako organu władzy wykonawczej w epoce saskiej, podkreślił, że w rzeczywistości na decyzje w ramach senatu, zapewniającego jedynie minimum funkcjonowania państwa, podejmowała wąska grupa senatorów, w danym okresie blisko związanych z dworem ${ }^{3}$. Teza Markiewicza z 1996 r. pozostawała również w opozycji do ustaleń innego wybitnego krakowskiego historyka, Józefa A. Gierowskiego, wskazującego dobitnie na szereg negatywnych zjawisk i procesów z doby panowania Wettynów, które doprowadzily do rozkładu mechanizmów ustrojowych państwa ${ }^{4}$. W niniejszym tekście podejmiemy próbę wskazania na szereg konsekwencji trwania unii polsko-saskiej dla funkcjonowania parlamentaryzmu Rzeczypospolitej, który bez wątpienia był kluczowy dla funkcjonowania państwa, tym bardziej w obliczu zmieniającego się otoczenia międzynarodowego państwa szlacheckiego, niepomiernego wzrostu potęgi militarnej wszystkich sąsiadów.

Po upływie ponad dwudziestu lat i pewnych postępach w badaniach nad tak zwaną epoką saską w Rzeczypospolitej, wypada raczej przychylić się do tezy, że państwo szlacheckie bez usprawnienia funkcjonowania sejmu jako najważniejszego organu ustrojowego, nie miało szans na przetrwanie przy ówczesnym układzie sił społecznych i specyfice funkcjonowania polityki w państwie polsko-litewskim, a także zmieniającym się układzie sił międzynarodowych. Tezie o możliwości zastąpienia sprawnego sejmu przez inne instytucje, akurat w tym konkretnym przypadku dziejowym przeczą badania, które ukazują upadek tych instytucji właśnie w epoce saskiej - zarówno sejmiki, jak i trybunały czy senat pogrążyły się w istotnym kryzysie. Żadna z tych instytucji bez reform nie miała najmniejszych szans na spełnienie narastających z upływem dziesięcioleci saskiego panowania oczekiwań na odbudowę

sprawnego, sprawiedliwego i ze wszech miar (tak wewnętrznych, jak i zewnętrznych)

2 M. Markiewicz, Rady senatorskie Augusta II (1697-1733), Wrocław 1988, s. 99.

3 Tenże, Senat jako organ władzy wykonawczej w epoce saskiej, [w:] Senat w Polsce. Dzieje i teraźniejszość. Sesja naukowa Kraków 25 i 26 maja 1993, Warszawa 1993, s. 145.

4 J.A. Gierowski, Cienie i blaski czasów saskich, [w: ] Na szlakach Rzeczypospolitej w nowożytnej Europie, red. A.K. Link-Lenczowski, Kraków 2008, s. 280 n. 
bezpiecznego państwa. Zupełnie płonne okazało się przekonanie, ugruntowane po pacyfikacji kraju przez Sejm niemy 1717 r., kończącej trwający przez dziesięciolecia okres wojen i konfliktów wewnętrznych, że rozbrojenie, obniżenie wydatków ponoszonych na armię, a wreszcie utrzymanie status quo, równowagi między majestatem i wolnością w dawnym kształcie ustrojowym Rzeczypospolitej pozwoli na zapewnienie długo wyczekiwanego pokoju i warunków do spokojnej odbudowy państwa. Potwierdzenie trwałości takich przekonań w narodzie politycznym Rzeczypospolitej w okresie panowania Augusta III ukazała niedawno dość przekonująco Zofia Zielińska ${ }^{5}$. Kres złudzeniom stopniowo kładły wydarzenia rozgrywające się pomiędzy brutalną ingerencją obcych państw w elekcję po śmierci Augusta II (wojna o sukcesję polską w latach 1733-1735), a bezceremonialnymi gwałtami i zniszczeniami, jakich dopuściły się armie rosyjska i pruska podczas wojny siedmioletniej na ziemiach neutralnego sąsiada w latach 1756-1763 - te ostatnie wydarzenia rozgrywały się paradoksalnie podczas przymusowej, niezwykle długiej rezydencji w Warszawie króla Augusta III.

Narastającego za panowania tego władcy oddolnego oczekiwania poprawy funkcjonowania państwa, nawet w zakresie ograniczonym do aukcji wojska ${ }^{6}$ czy naprawy sądownictwa ${ }^{7}$, nie dało się przeprowadzić inaczej, jak poprzez skuteczne uchwały sejmowe, a te po 1736 r. okazały się zupełnie niemożliwe do osiągnięcia. Szeroko zakrojone reformy, jakie zaczęto realizować konsekwentnie od 1764 r., czyli po zakończeniu unii personalnej z Saksonią, nie miały już jednak szans na sukces, gdyż były rozpoczęte zbyt późno, przy potężnych już wówczas ograniczeniach ze strony Rosji i wspieranej przez nią, słabnącej, ale wciąż istotnej opozycji, szermującej ha-

5 Z. Zielińska, Echa dokonań Sejmu Niemego w czasach Augusta III i Stanisława Augusta (rekonesans), [w: Sejm Niemy. Między mitem a reformą państwa, red. M. Zwierzykowski, Warszawa 2019, s. 286-327.

6 H. Krawczak, Sprawa aukcji wojska na sejmach za panowania Augusta III, Studia i Materiały do Dziejów Wojskowości 7 (1961), cz. 2. Zob. też: T. Ciesielski, Armia koronna w czasach Augusta III, Warszawa 2009, s. 19 n.

7 J. Michalski, Studia nad reforma sądownictwa i prawa sądowego w XVIII wieku, Warszawa 1958. Na temat narastającej presji narodu politycznego na poprawę funkcjonowania sądownictwa, szczególnie u schyłku epoki saskiej, a także na nieustające trwanie przekonania o sprawiedliwości jako fundamencie państwa zob. M. Zwierzykowski, „Sine iustitia in libertate żyć nie chcemy”. Prawo i sprawiedliwość $w$ dyskursie politycznym kampanii sejmowych lat 1696-1762, [w:] Wartości polityczne Rzeczypospolitej obojga narodów, red. A. Grześkowiak-Krwawicz, współpraca J. Axer, Warszawa 2017, s. 264-288. 
słami „złotej wolności”. Tymczasem proces reform w specyficznym na swój sposób państwie demokratycznym, jakim była Rzeczpospolita, musiał być długotrwały.

Pojawiają się zatem na tym etapie liczne pytania. Dlaczego odgórnych reform i zmian, nawet w skromnym wymiarze, nie rozpoczęto wcześniej? Dlaczego system parlamentarny państwa szlacheckiego, czyli sejm powiązany z systemem sejmików przedsejmowych i relacyjnych, które jeszcze w XVII w. spełniały do pewnego stopnia swoją rolę, za panowania dynastii saskiej uległ całkowitej blokadzie? Czy za wszystko obarczyć winą można obcych monarchów? Niniejszy, krótki z konieczności tekst z pewnością nie odpowie na wiele wątpliwości, na przeszkodzie często stoi wciąż mało satysfakcjonujący postęp badań, jednak dokonania kilku pokoleń historyków pozwalają już dziś na sformułowanie pewnych hipotez i wskazanie dalszych kierunków naukowych poszukiwań.

Jak już wspomniano, parlamentaryzm dawnej Rzeczypospolitej składał się ze skomplikowanego mechanizmu wiążącego sejm - od 1468 r. już z udziałem wybieranych posłów, a od końca XVI w. zdecydowanie najważniejszą instytucję w państwie ${ }^{9}$, z senatem (zbierającym się na przed - i posejmowych zebraniach) oraz sejmikami ziemskimi ${ }^{10}$, które jednocześnie stawały się fundamentem samorządności terytorialnej - kwestia ta nie była również bez wpływu na funkcjonowanie parlamentaryzmu. Stanowiące element pośredni sejmiki generalne zanikły w Koronie, jak i w Wielkim Księstwie Litewskim jeszcze w XVII w., a próby ich wskrzeszenia w końcu XVII i początku XVIII w. były jedynie symboliczne ${ }^{11}$. Rolę zgromadzeń generalnych przejęły, słusznie zresztą, sesje prowincjonalne odbywane podczas sejmów.

W okresie 66 lat trwania unii polsko-saskiej zwołano aż 41 sejmów (licząc od sejmu koronacyjnego 1697 r., uwzględniając dwa nadzwyczajne sejmy nie liczone $\mathrm{w}$ dotychczasowych zestawieniach chronologicznych - elekcję 1704 r. i walną radę

8 A. Lityński, Sejmiki ziemskie 1764-1793. Dzieje reformy, Katowice 1988, s. 64-65.

9 W. Uruszczak, Historia państwa i prawa polskiego, t. 1: 966-1795, Warszawa 2013, s. 135 n. tam charakterystyka ukształtowanych za Jagiellonów zasad ustroju parlamentarnego Rzeczypospolitej; 550-lecie polskiego parlamentaryzmu. Sejm Królestwa Polskiego i Rzeczypospolitej Obojga Narodów, Warszawa 2018, s. $8 \mathrm{n}$.

10 A. Pawiński, Rzady sejmikowe w Polsce 1572-1795 na tle stosunków województw kujawskich, wyd. 2, oprac. H. Olszewski, Warszawa 1978, s. 49-50; W. Kriegseisen, Sejmiki Rzeczypospolitej szlacheckiej w XVII i XVIII wieku, Warszawa 1991, s. 15.

11 A. Rachuba, Sejmiki generalne Wielkiego Księstwa Litewskiego w Wotkowysku i Stonimiu, [w:] Między Wschodem a Zachodem. Studia z dziejów Rzeczypospolitej w epoce wczesnonowożytnej, red. J. Staszewski, Toruń 2002, s. 42-56; tenże, Wielkie Księstwo Litewskie w systemie parlamentarnym Rzeczypospolitej w latach 1569-1763, Warszawa 2002, s. 152 n. 
warszawską 1705 r.). Daje to pozornie całkiem niezłą średnią - sejm wypadać miał częściej niż przewidywane przez prawo co dwa lata dla sejmów zwyczajnych. Oczywiście bliższa analiza chronologii sejmów pokazuje, że w szczególności do 1717 r. nie odbywały się one ani regularnie, ani w sposób szablonowy. Coraz rzadziej korzystano z instytucji sejmów nadzwyczajnych - zwołano ich jedynie sześć ${ }^{12}$, pojawiły się nowe $\mathrm{w}$ dotychczasowej praktyce walne rady senatu $\mathrm{z}$ delegatami sejmikowymi (z których niektóre miały charakter zbliżony do sejmów) ${ }^{13}$. Skuteczność obrad, nienajgorsza jeszcze w pierwszej połowie panowania Augusta II, uległa całkowitemu załamaniu za panowania jego syna - nawet pomimo powrotu do regularności zwoływania obrad parlamentu w oparciu o stały termin ustalony na Sejmie Niemym - co dwa lata, na pierwszy poniedziałek po święcie św. Michała ${ }^{14}$. Spośród 41 sejmów uchwaleniem konstytucji zakończyło się jedynie 14 (34\%). Z tych 14 sejmów tylko jeden przypadł na czasy panowania Augusta III ${ }^{15}$. Dobrą podstawę porównawczą dla tej sytuacji mogą stanowić sejmy z okresu rządów Jana III. W latach 1674-1696 zwołano ich w sumie 12, a z nich połowa zakończyła się fiaskiem (aż pięć sejmów zerwano jednak $\mathrm{w}$ drugiej połowie panowania tego władcy) ${ }^{16}$. Trzeba zatem dobitnie podkreślić, że upadek sprawności sejmu, z jego najgorszymi przejawami, miał miejsce już za króla rodaka, Jana III Sobieskiego, a co więcej, w pierwszym okresie panowania Wettynów efektywność sejmu mierzona liczbą uchwalonych konstytucji nawet wzrosła w stosunku do okresu lat 1688-1695. Później już jednak było znacznie gorzej.

Negatywne zjawisko stosowania liberum veto i zrywania obrad sejmowych, już za Sobieskiego przeniosło się na sejmiki, w okresie panowania Wettynów dokonując dalszych spustoszeń ${ }^{17}$. Fragmentaryczne na razie badania nie dają obrazu dla całej Rzeczypospolitej, ale dziś wiemy, że w Koronie niezwykle często zrywano sejmi-

12 W. Konopczyński, Chronologia sejmów polskich 1492-1793, Archiwum Komisji Historycznej 4 (16) (1948), nr 3, s. 127-169; M. Zwierzykowski, „Sine iustitia in libertate żyć nie chcemy”, s. $268-270$.

13 Jedna z takich walnych rad, w 1710 r. została wręcz uznana za sejm, a uchwalone przez nią prawa za konstytucje drukowane w Volumina legum (Vol. leg., t. 6, s. 69-106).

14 J. Michalski (red.), Historia sejmu polskiego, t. 1, Warszawa 1984, s. 307.

15 W. Konopczyński, Chronologia sejmów, s. 159-166.

16 R. Kołodziej, „Ostatni wolności naszej klejnot”. Sejm Rzeczypospolitej za panowania Jana III Sobieskiego, Poznań 2014, s. 454-458.

17 A. Lityński, Sejmiki ziemskie, s. 32-33; M. Zwierzykowski, Liberum veto w praktyce wielkopolskiej działalności sejmikowej w czasach saskich, Biblioteka Epoki Nowożytnej 4 (2017), nr 1, s. $97 \mathrm{n}$. 
ki (również te przedsejmowe) w Wielkopolsce i Prusach Królewskich ${ }^{18}$, ale i gdzie indziej. W Wielkim Księstwie Litewskim posłów nie wybierano czasem na sejmy $\mathrm{z}$ - lepiej jak na razie przebadanych - sejmików wileńskiego ${ }^{19}$, trockiego ${ }^{20}$, brzesko-litewskiego ${ }^{21}$, a szczególnie często z sejmiku mścisławskiego (na 14 sejmików przedsejmowych za Augusta III aż 8 zerwano), jak to ostatnio ustalił Andrej Macuk ${ }^{22}$. Co gorsza, w procederze zrywania obrad obok najczęstszych przyczyn lokalnych i rywalizacji głównych stronnictw magnackich, brało udział również stronnictwo dworskie (coraz częściej za panowania Augusta III - choć początek negatywnego zjawiska pojawił się już za Jana Kazimierza) ${ }^{23}$. Najczęstszą przyczyną zrywania był konflikt między ugrupowaniami (fakcjami) politycznymi wokół dokonywanych podczas obrad wyborów: posłów, deputatów, komisarzy i innych funkcjonariuszy sejmikowych ${ }^{24}$. Jednocześnie za panowania Wettynów mocno ograniczono udzielanie zgody królewskiej na odbywanie powtórnych sejmików przedsejmowych, co wcześniej często pozwalało dokonać wyboru posłów pomimo konfliktów.

Kolejną z obserwacji, którą należy poczynić przy analizie specyfiki funkcjonowania systemu parlamentarnego Rzeczypospolitej w dobie unii z Saksonią, jest fakt zaniku zwoływania zgromadzeń sejmików relacyjnych. Jeszcze w XVII w. dość częstą praktyką, obok zwykłego deklarowania terminów relacji poselskich w konstytucjach sejmowych, było zwoływanie ich również po zerwanych sejmach, na mocy

18 S. Achremczyk, Życie sejmikowe Prus Królewskich w latach 1647-1772, Olsztyn 1999, s. 209-210.

19 R. Jurgaitis, Vilniaus seimelio veikla 1717-1795 m., Kaunas 2007, s. 220-230.

20 A.B. Zakrzewski, Sejmiki Wielkiego Księstwa Litewskiego XVI-XVIII w. Ustrój i funkcjonowanie: sejmik trocki, Warszawa 2000, s. 223 n.

21 D. Konieczna, Ustrój i funkcjonowanie sejmiku brzesko-litewskiego w latach 1565-1763, Warszawa 2013, s. 174 n.

22 A. Macuk, Sejmiki województwa mścistawskiego za panowania Augusta III, [w: Unie międzypaństwowe. Parlamentaryzm. Samorządność. Studia z dziejów ustroju Rzeczypospolitej Obojga Narodów, red. W. Uruszczak, Z. Noga, M. Zwierzykowski, K. Fokt, Warszawa 2020, s. 350-376.

23 J. Dygdała, Życie polityczne Prus Królewskich u schyłku ich związku z Rzecząpospolita w XVIII wieku, Toruń 1984, s. 20; M. Czeppe, Kamaryla Pana z Dukli. Ksztattowanie się obozu politycznego Jerzego Augusta Mniszcha 1750-1763, Kraków 1998, s. 230.

24 A. Lityński, Sejmiki ziemskie, s. 36-37. Jak katastrofalne skutki miały konflikty personalne wykazał ostatnio na przykładzie sejmików elekcyjnych kandydatów na urzędy sądowe ziemskie K. Mikulski, Kryzys sądownictwa ziemskiego i podkomorskiego w Koronie w XVII-XVIII wieku. Analiza topograficzna i chronologiczna, [w: Sic erat in votis. Studia i szkice ofiarowane Profesorowi Zbigniewowi Anusikowi, Rzeczpospolita w czasach nowożytnych, red. M. Karkocha, P. Robak, Łódź 2017, s. 255-282. 
uniwersałów królewskich, na prośbę posłów lub senatorów. August II ograniczył ten zwyczaj, a jego syn ostatecznie zakończył - ostatnie sejmiki relacyjne zwołano po sejmie $1736 \mathrm{r}^{25}$ Jest to wyraźny symptom braku zainteresowania władców podejmowaniem bezpośredniego dialogu ze stanem szlacheckim, włączeniem go w szukanie rozwiązań nadzwyczajnych w obliczu coraz częstszego rwania sejmów. Jednocześnie badacze potwierdzają, że jednym z narzędzi do wprowadzenia planowanych reform państwa mogła być sprawnie funkcjonująca klientela, której naturalną areną działania były sejmiki ${ }^{26}$. Znamienny w tym zakresie może być przypadek odmawiania z powodów formalnych audiencji posłom wybranym przez szlachtę po zerwanych sejmikach, których wysyłano z petycjami do króla ${ }^{27}$. Z pewnością ułatwiało to życie władcy, zmniejszając liczbę uciążliwych audiencji, ale jednocześnie dowodziło braku zainteresowania lokalnymi sprawami odległego państwa, co było istotne przy ewentualnych próbach budowaniu poparcia dla jego naprawy. Dla lepszej ilustracji można w tym miejscu przytoczyć dane statystyczne pochodzące $\mathrm{z}$ analizy wszystkich przypadków wysyłania posłów do władców i innych osób z sejmiku Wielkopolski właściwej w XVIII w. Na łączną liczbę wysłanych w latach 1699-1793 143 poselstw, aż 52 kierowano z sejmiku wielkopolskiego do królów: 26 do Augusta II, 10 do Stanisława I, zaledwie 5 do Augusta III i 11 do Stanisława Augusta. Dodatkową kwestią jest również zawartość instrukcji poszczególnych poselstw. Z upływem czasu stawała się ona coraz bardziej ceremonialna - za Stanisława Augusta posłom zlecano już niemal wyłącznie podziękowania i pochwały dla monarchy ${ }^{28}$.

Na wspomniane wyżej 41 sejmów w latach 1697-1763, aż 31 zwołano do Warszawy, 7 do Grodna, 2 koronacyjne do Krakowa, a 1 do Lublina ${ }^{29}$. Dość wyraźnie

25 Akta sejmikowe województw poznańskiego i kaliskiego. Lata 1733-1763, wyd. M. Zwierzykowski, Warszawa 2015 - tam edycja wszystkich uniwersałów królewskich zwołujących sejmy i sejmiki za panowania Augusta III oraz towarzyszących im instrukcji królewskich.

26 Z. Zielińska, Mechanizm sejmikowy i klientela radziwiłtowska za Sasów, Przegląd Historyczny, 52 (1971), z. 3, s. 93; A. Perłakowski, Michat Fryderyk Czartoryski, podkanclerzy litewski wobec obsady urzędów centralnych, ziemskich i trybunalskich $w$ Wielkim Księstwie Litewskim w 1744 roku, [w: ] Sic erat in votis, s. 317.

27 Zob. na przykład informację w liście kanclerza A.S. Załuskiego biskupa chełmińskiego do stolnika litewskiego P.P. Sapiehy, o nieuznaniu za posłów do króla przedstawicieli wysłanych przez Wielkopolan do Drezna po zerwanym sejmiku gospodarskim 12 IX 1741 r. (Akta sejmikowe 1733-1763, s. 306).

28 M. Zwierzykowski, Dyplomacja sejmikowa w XVIII wieku na przykładzie wielkopolskim - tekst referatu wygłoszonego na konferencji w Łodzi w 2019 r., w przygotowaniu do druku.

29 W. Konopczyński, Chronologia sejmów polskich 1493-1793, Kraków 1948. 
widać, że Wettynowie nie przestrzegali prawa z 1673 r. o alternacie litewskiej, stanowiącego, że co trzeci sejm powinien odbyć się na terenie Wielkiego Księstwa Litewskiego, nawet pomimo usilnych starań o to samych Litwinów i uchwalenia specjalnej konstytucji w tej sprawie w $1703 \mathrm{r}^{30}$ Sejmy grodzieńskie przypadły na lata 1718 , 1726, 1728 (ostatecznie odwołany), 1729, 1730, 1744 i 1752 ${ }^{31}$. August II próbował co prawda powrócić do tego prawa w drugiej części swego panowania, po 1717 r., ale wyniki nie były zadowalające, jego syn podjął już tylko dwie próby, obie bezskuteczne. Niechęć do sejmowania na Litwie, oprócz wcześniejszych przyczyn i przeszkód zgłaszanych przede wszystkim przez szlachtę z Korony, dyktowana była odległością Grodna od najczęstszego miejsca rezydencji władców, jakim w przypadku Wettynów była jednak Saksonia.

W tym miejscu koniecznie należy wskazać ten fakt jako jeden z poważnych powodów pogłębienia i wreszcie utrwalenia kryzysu ustrojowego państwa. Władcy sascy i królowie polscy zdecydowaną większość czasu spędzali poza Rzecząpospolitą, a ich pobyty, nawet jeśli dość często stawały się regularne, były krótkie i nie niosły ze sobą stworzenia stolicy-centrum państwa z prawdziwego zdarzenia, siedziby dworu i najważniejszych w państwie ludzi. Co więcej, częsta obecność w Saksonii wiązała się z silnym zaangażowaniem politycznym w sprawy Elektoratu i jego pozycji w Rzeszy - miało to wielokrotnie negatywny wpływ na sprawy Rzeczypospolitej (np. nieodbywanie zaplanowanych już sejmów ${ }^{32}$ ). Brak w państwie nieustającej obecności monarchy z całą pewnością wpływał negatywnie na poziom życia politycznego - nie mogły tego rekompensować częste i kosztowne wyprawy obywateli Rzeczypospolitej do Saksonii, a nawet ich dłuższe tam pobyty ${ }^{33}$. Za panowania Augusta II na krótko, a za jego syna już niemal na stałe pojawił się jeszcze gorszy zwyczaj przybywania do Rzeczypospolitej króla jedynie do pogranicznej Wschowy,

\footnotetext{
30 Konstytucja „Sejm trzeci w Wielkim Księstwie Litewskim” z 1673 r. (Vol. leg., t. 5, s. 67).

31 W. Konopczyński, Chronologia sejmów polskich; R. Kołodziej, Sejm z 1718 roku na tle pierwszych sejmów grodzieńskich. Uwagi na temat wybranych elementów procedury sejmów w Grodnie, [w: ] W podróży przez wiek osiemnasty... Studia i szkice z epoki nowożytnej, red. A. Perłakowski, M. Wyszomirska, M. Zwierzykowski, Kraków 2015, s. 41 n.

32 Sejm 1728 r. w Grodnie został odwołany w ostatniej chwili, już po sejmikach przedsejmowych, sejmu 1742 r. wcale nie zwołano, nie odbył się sejm 1756 r., z powodu oblężenia króla w Dreźnie przez wojska pruskie. Ostatecznie nie zwołano też sejmu nadzwyczajnego w 1755 r., do którego przygotowania były mocno zaawansowane (Akta sejmikowe województw poznańskiego i kaliskiego. Lata 1696-1732, wyd. M. Zwierzykowski, Poznań 2008, s. 1048; Akta sejmikowe 1733-1763, s. 310, 535, 561).

33 J. Staszewski, Polacy w osiemnastowiecznym Dreźnie, Wrocław 1986, s. 91 n.
} 
dla zebrania senatu i podpisania niezbędnych dokumentów ${ }^{34}$. Proces zaniku istnienia centrum państwa z prawdziwego zdarzenia, jakim powinna być stolica, nie rozpoczął się jednak za Wettynów, co trzeba wyraźnie przypomnieć. Już Jan III znacznie częściej przebywał w obozach wojskowych lub na ukochanej Rusi, w dobrach prywatnych, do Warszawy zjeżdżając jedynie dla odbycia sejmów bądź załatwienia najpilniejszych spraw - wiele rad senatu zwoływał poza stolicą, m.in. do Żółkwi, Gdańska, Lwowa, Jaworowa, a nawet Wilanowa ${ }^{35}$.

Nie bez znaczenia były tu również osobiste cechy Augusta III, który, jak niezwykle trafnie napisał Adam Perłakowski w swej znakomitej książce poświęconej wieloletniemu przyjacielowi i pierwszemu ministrowi króla, był „władcą unijnego państwa, miał bardzo duże przywiązanie do tradycji domu Wettynów i podkreślał na każdym kroku swój królewski majestat. August III chciał wieść spokojne życie, pozbawione wstrząsów, urozmaicane polowaniami, festynami, karuzelami, przedstawieniami operowymi, teatralnymi i baletowymi (trzeba przyznać, że na bardzo wysokim poziomie). [...] August III był [...] zaledwie biernym obserwatorem wydarzeń, podatnym na wpływ otoczenia" - co wykorzystał bez skrupułów Heinrich Brühl, stając się w $1738 \mathrm{r}$. prawą ręką władcy na resztę jego panowania ${ }^{36}$.

Dość regularne zwoływanie sejmów przez obu Wettynów, szczególnie po 1717 r., w obliczu ich coraz mniejszej skuteczności, stopniowo doprowadziło do uczynienia z parlamentu swego rodzaju ceremonialnego teatrum, które coraz mniej przypominało sejmy z minionej epoki. Wysyłane przed każdym sejmem ekspedycje przedsejmowe stawały się coraz bardziej szablonowe i sformalizowane - teksty bardzo często kopiowano i powtarzano po wielokroć, nie dbając nawet o kamuflowanie tego zjawiska ${ }^{37}$. Prowadzone często nieudolnie kampanie, powierzane najczęściej nielicznej grupie magnatów i urzędników, stanowiących aktualnie zaplecze dworu, bez osobistego i pełnego zaangażowania monarchy (jak to miało miejsce za panowania Stanisława Augusta $\left.{ }^{38}\right)$, nie miały szansy wykrzesać impulsu, który mógłby dopro-

34 M. Markiewicz, Rady senatu za Augusta III, Zeszyty Naukowe UJ, Prace Historyczne, 77 (1985), s. 69-89.

35 J. Krupa, Rady senatu za Jana III Sobieskiego (1674-1696), Studia Historyczne, 35 (1992), z. 3, s. 307-329.

36 A. Perłakowski, Kariera i upadek królewskiego faworyta. Aleksander Józef Sułkowski w latach 1695-1738, Kraków 2013, s. 253, 258.

37 Wstępna próba analizy wybranych aspektów ekspedycji królewskich na sejmiki przedsejmowe zob. M. Zwierzykowski, „Sine iustitia in libertate żyć nie chcemy”, s. 264 n.

38 W. Filipczak, Życie sejmikowe prowincji wielkopolskiej w latach 1780-1786, Łódź 2012, s. 622 
wadzić do konsolidacji szlachty wokół jakiegoś programu. Symbolem tego procesu może być zjawisko, które zapoczątkowano już za Augusta III, polegające na wyznaczaniu na posła królewskiego na sejmik przedsejmowy również osób małoletnich, uczniów szkół - to oczywiście symbol, ale jakże symptomatyczny ${ }^{39}$.

Ociężałość Augusta III w działaniu, brak zdecydowania, pomysłu na rozwiązanie kryzysu systemu parlamentarnego państwa przejawiały się również przy korzystaniu z tradycyjnych, nie budzących zastrzeżeń form organizacyjnych związanych z sejmem - posejmowych rad senatu. Dobrym przykładem może być sytuacja z sejmem grodzieńskim 1752 r., obradującym w dniach 2-26 października i tradycyjnie zerwanym $^{40}$. Złe przeczucia wobec tego sejmu świeżo mianowany podkanclerzy litewski Michał Antoni Sapieha miał już 17 października i tak opisał je w liście do brata, biskupa koadiutora wileńskiego Józefa Stanisława Sapiehy: „Sejm nasz piękne miawszy początki, teraz opieszałym i podejrzanym o dojściu idzie krokiem, czas resztę odkryje. To zaś pewna, iż ustawiczna sejmów exanicyja irritat co bardziej konfidencyją status, pomnaża cięższe i fatalniejsze niezgody concivium, na koniec, oby nie była periodem upadku państwa"41. 24 października zerwanie sejmu było już niemal pewne, o czym ponownie donosił swemu bratu podkanclerzy ${ }^{42}$. August III zaniedbał jednak zwołania rady posejmowej na miejscu w Grodnie, wpadając na pomysł zwołania senatorów do Warszawy, gdzie mógłby się wygodnie zatrzymać w drodze powrotnej do Saksonii. Tak skomentował to 1 XI 1752 r. podkanclerzy litewski: „Po zerwanym sejmie chcąc J.K.M. paterne radzić [de] bono publico, konwokuje nas na senatus consilium do Warszawy i z tym wczoraj sztafetę przysłał, ale wątpię gdyby znaczny numerus znalazł się senatu, bo z Grodna każdy do domu pojechał i retrogradum nie zechce uczynić passum”33. 9 listopada niezdecydowany król podjąl jednak decyzję, słuchając słusznych podszeptów o nikłości szans na przyjazd senatorów do stolicy. Podkanclerzy tak opisał tę sytuację: „Lubo zostająca bez powszechnej rady R.P. potrzebowałaby w dolegliwościach swoich przyzwoitego a senatus consilio

39 Na przykład w 1761 r. posłem królewskim na sejmik przedsejmowy w Środzie został niespełna dwunastoletni wówczas Jakub Szołdrski, przybyły na obrady w asyście swych jezuickich nauczycieli (Akta sejmikowe 1733-1763, s. 666). Brak badań nad posłami królewskimi na sejmiki $\mathrm{w}$ czasach saskich uniemożliwia poznanie skali tego zjawiska.

40 W. Konopczyński, Chronologia, s. 165.

41 List Michała A. Sapiehy do Józefa S. Sapiehy biskupa koadiutora wileńskiego - Grodno, 17 X 1752 r. (Biblioteka Litewskiej Akademii Nauk w Wilnie, F.139-4063, k. 418).

42 List Michała A. Sapiehy do Józefa S. Sapiehy - Grodno, 24 X 1752 r. (tamże, k. 417).

43 List Michała A. Sapiehy do Józefa S. Sapiehy - Grodno, 1 XI 1752 r. (tamże, k. 416). 
opatrzenia, jednak kiedy po niedoszłym sejmie i to nie nastąpiło, remonstrowaliśmy J.K.M., iż praepostere złożone w Warszawie senatus consilium byłoby ekstraordynaryjnym, bo by nie miało postcomitialis senatus consilii formam, dlatego zdało się J.K.M. już nie składać onego. Zaczym wyjazd pański w tych dniach jest dysponowanym" ${ }^{\text {"4 }}$. Miesiąc później August III miał ponoć żałować swego pierwotnego zaniedbania i niezwołania rady zaraz po zerwanym sejmie, podkanclerzy skomentował to już dość sarkastycznie: „Król jm. zaczyna żałować, że mimo rady nasze wyjazd swój pospieszył z Grodna, nie złożywszy tamże senatus consilium, chciałby to reparare, ale podobno łatwiej jest amittere ocasiones, niżeli amissos revocare" ${ }^{45}$. W świetle tej sytuacji raczej jako mrzonka brzmieć muszą rozważania na temat jakichkolwiek szans na podjęcie działań konfederackich przez stronnictwo dworskie - Brühla i odchodzących powoli w $1752 \mathrm{r}$. od popierania dworu Czartoryskich ${ }^{46}$.

Warto w tym miejscu wspomnieć o kolejnej wadzie, jaką posiadały już u zarania rządy Wettynów z perspektywy państwa szlacheckiego - był to brak pełnego zrozumienia jego mechanizmów, a nawet pogarda i lekceważenie dla wielu elementów ustrojowych. Taki kierunek doprowadził między innymi do ograniczenia zaangażowania w sprawy państwowe budowanego od dziesięcioleci systemu sejmikowego, w którym swoją aktywność polityczną realizowała średnia szlachta, a częstymi uczestnikami były również rzesze mniej zamożnych obywateli Rzeczypospolitej ${ }^{47}$. Nie byłoby to może krokiem jednoznacznie błędnym, gdyby równocześnie udało się przeprowadzić reformy sejmu i rozpocząć głębsze reformy struktur państwa. Bez tego jednak podejmowane działania przypominały raczej leczenie, urojonej po części choroby, przy pomocy amputacji. Likwidacja limity sejmikowej i zmniejszenie kompetencji samorządu szlacheckiego przyniosło Augustowi II pozorne poczucie sukcesu po 1717 r., jednocześnie paradoksalnie stanowiło początek końca prób między innymi wykorzystania limity do poprawy systemu parlamentarnego ${ }^{48}$.

\footnotetext{
44 List Michała A. Sapiehy do Józefa S. Sapiehy - Grodno, 9 XI 1752 r. (tamże, k. 416).

45 List Michała A. Sapiehy do Józefa S. Sapiehy - Bychów, 1 XII 1752 r. (tamże, k. 404).

46 Z. Zielińska, Walka „Familii” o reformę Rzeczypospolitej w latach 1743-1752, Warszawa 1983, s. 339; A. Macuk, Baracba magnackich grupowak u WKL (1717-1763 gg.), Minsk 2010, s. 363.

47 M. Zwierzykowski, Samorząd sejmikowy województw poznańskiego i kaliskiego w latach 1696-1732, Poznań 2010, s. 92 n.; szczególnie w okresie zaburzeń wewnętrznych, silnych konfliktów stronnictw czy silnego zagrożenia z zewnątrz na sejmiki przybywała liczne również drobna szlachta, co znajduje odbicie w oblatowanych czasem w księgach grodzkich manifestacjach podpisanych przez setki osób (np. Akta sejmikowe 1733-1763, s. 529).
}

48 M. Zwierzykowski, Negocjacje pacyfikacyjne w okresie Sejmu Niemego (1716-1717). Porażka 
Ostatecznie sejm 1726 r., nieufny wobec władcy, zakazał mocą konstytucji limitowania sejmów ${ }^{49}$ - zamknięto tym samym kolejną, potencjalną drogę do bardziej zdecydowanych prób naprawy państwa z wykorzystaniem możliwości, jaką dawało istniejące wcześniej rozwiązanie ustrojowe.

Do innego z nich, konfederacji, August II również był usposobiony wyjątkowo negatywnie, wiedziony doświadczeniami pierwszej połowy swego panowania, kiedy jednak konfederowano się w obliczu wojny i poważnych konfliktów wewnętrznych, często powstałych nie bez udziału Wettyna. Politykę tę przejął po ojcu zdecydowanie mniej uzdolniony politycznie August III - J. Dygdała stwierdził nawet, że „otoczenie Augusta III cierpiało na swego rodzaju kompleks konfederacji, która korzystając z pomocy państw obcych doprowadzi do detronizacji”" ${ }^{50}$. Unikanie przez Augusta III myślenia o konfederacji jak nadzwyczajnym narzędziu dworu służącym do przełamania impasu, w jakim utkwił system parlamentarny, było tym bardziej katastrofalne w skutkach, jeśli przypomnieć, że poważne reformy prowadzone po 1764 r. były możliwe wyłącznie z wykorzystaniem tego środka - działań sejmów skonfederowanych ${ }^{51}$. Oczywiście nie bez znaczenia był również jednoznacznie negatywny stosunek Rosji do reform w Rzeczypospolitej, w tym szczególnie z wykorzystaniem konfederacji, przede wszystkim konsekwentny w latach czterdziestych i pięćdziesiątych XVIII w. August III był w tej kwestii jednak bardziej sojusznikiem wschodniego sąsiada niż własnych poddanych. W takiej konfiguracji wszelkie plany konfederacyjne, niezależnie przez kogo zgłaszane i w jakim zakresie, nie miały żadnych szans nawet na symboliczny sukces.

W 2010 r. Monika Wyszomirska, podsumowując swoją książkę poświęconą politycznym polemikom lat 1734-1763, niezwykle trafnie zdiagnozowała problem: „Za upadek większości sejmów były odpowiedzialne rodzime siły destrukcyjne, współpracujące często z obcymi mocodawcami. [...] Działo się tak niezależnie od tego,

partykularyzmów i sukces racji stanu, [w:] Spory o państwo w dobie nowożytnej. Między racją stanu a partykularyzmem, red. Z. Anusik, Łódź 2007, s. 175 n.; M. Zwierzykowski, Geneza i konsekwencje reform sejmików w konstytucjach Sejmu Niemego, [w: Sejm Niemy, s. 241-265; Historia sejmu polskiego, t. 1, s. 344 .

49 Konstytucja „Securitas sejmów walnych” z 1726 r. (Vol. leg., t. 6, s. 209).

50 J. Dygdała, Życie polityczne, s. 20.

51 Z. Zielińska poświęciła wiele uwagi badaniu planów reformy państwa za panowania Augusta III, w tym również potencjalnych możliwości wykorzystania konfederacji. Zdaniem tej autorki realizację wszelkich planów uniemożliwiała Rosja, wydaje się jednak, że i brak przekonania (wręcz niechęć) ze strony władcy Rzeczypospolitej miał niebagatelne znaczenie. Z. Zielińska, Walka „Familii”; Z. Zielińska, Echa dokonań, s. 327. 
która z partii występowała w danym czasie w roli stronnictwa dworskiego. Jeśli przyjąć, że w ówczesnym życiu politycznym istniał stan zbliżony do anarchii, rozumianej jako zupełny rozkład instytucji państwowych, trzeba przyznać, że jednocześnie $\mathrm{z}$ wielu stron podejmowano próby jej usunięcia. To, że działania takie prowadziły do pogłębiania się stanu tejże anarchii, jest swoistym paradoksem, ale też dowodem, na zupełny brak spoiwa zdolnego podźwignąć całość, czyli wymykający się spod czyjejkolwiek kontroli, jak mówiono, ster państwa" ${ }^{2}$. Wydaje się, że ster państwa powinien spoczywać w rękach monarchy, u schyłku epoki panowania Wettynów w Rzeczypospolitej tak już jednak nie było.

Kończąc te krótkie z konieczności wywody trzeba podkreślić, że nie było celem niniejszego tekstu podejmowanie polemiki w kwestii ogólnej oceny epoki saskiej w Rzeczypospolitej Obojga Narodów, którą od czasów badań Jacka Staszewskiego musimy z pewnością realizować znacznie szerzej, wielowymiarowo, $\mathrm{w}$ wielu aspektach. Dokonywana w taki sposób ocena z pewnością pozwala na uzyskanie nieco jaśniejszego obrazu przemian i dokonań państwa w latach 1697-1763. Z perspektywy jednak oceny funkcjonowania jego ustroju i polityki wewnętrznej obraz ten, pomimo prób podejmowanych przez niektórych historyków, musi być raczej negatywny. Nie zawsze oczywiście winę za kryzys ponosili wyłącznie Wettynowie, wiele procesów na dobre zaczęło się już wcześniej, inne były od nich niezależne. $\mathbf{Z}$ calą pewnością władcy z Saksonii nie znaleźli żadnego skutecznego sposobu na reformę Rzeczypospolitej i przywrócenie jej choć części pozycji, jaką zajmowała wcześniej. Podejmując różne działania, nie zawsze uzyskiwali efekt zbieżny z oczekiwaniami. Wymuszając pewne zmiany, w wymiarze długofalowym powodowali pogłębianie kryzysu. Na pewno nie czynili tego z celowego zamiaru doprowadzenia państwa do upadku, jednak nie zmienia to wniosku, że coraz lepiej poznawane fakty nie świadczą najlepiej o pozytywnym wyniku bilansu ustrojowo-politycznego unii Korony i Wielkiego Księstwa Litewskiego z Saksonią.

\section{Summary}

This article attempts to provide answers to several research questions related to the consequences of representatives of the House of Wettin ruling the Polish-Lithuanian Commonwealth to the country's state organisation. Special attention has been devoted to the parliamentary system of key importance to the entire state. Back in the $18^{\text {th }}$ century, the

52 M. Wyszomirska, Między obroną wolności a naprawa państwa. Rzeczpospolita jako przedmiot polemik politycznych $w$ dobie panowania Augusta III (1734-1763), Warszawa 2010, s. 258. 
system consisted of several elements: the general sejm combining the three estates, the local parliaments as well as pre - and post-parliamentary senate counsels. During the reigns of Augustus II and Augustus III, all the components of the structure suffered crisis and neither ruler managed to put a stop to this negative process. This led to a complete impasse in the Polish parliamentary system in 1733-1763 which turned into some sort of a spectacle. It was not until the parliamentary reforms introduced by Stanisław August Poniatowski following confederations that the process of repairing and upgrading the state could commence.

Translated by Ewa Dratwa

Prof. UAM dr hab. Michał Zwierzykowski

Zakład Historii Nowożytnej do XVIII wieku

Wydział Historii

Uniwersytet im. Adama Mickiewicza w Poznaniu

ul. Uniwersytetu Poznańskiego 7

61-614 Poznań

e-mail: mzwi@amu.edu.pl

Nadesłany 17 I 2020

Nadesłany po poprawkach recenzyjnych 28 I 2020

Zaakceptowany 10 II 2020 